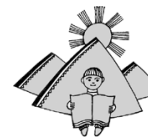

doi: $10.15330 / m s u c .2020 .23 .143-147$

\title{
Ореста Ткачук,
}

кандидат педагогічних наук, доцент, ДВНЗ «Прикарпатський національний університет імені Василя Стефаника» (м. Івано-Франківськ, Україна)

\author{
Oresta Tkachuk, \\ Candidate of Pedagogic Sciences, Associate Professor, \\ Vasyl Stefanyk Precarpathian National University \\ (Ivano-Frankivsk, Ukraine) \\ oresta.tkachuk@pnu.edu.ua \\ ORCID ID 0000-0003-1757-0790
}

удк 8.372

\section{ФРАЗЕОЛОГІЗМИ ЯК ЗАСІБ РОЗВИТКУ МОВЛЕННЯ ТРЕТЬОКЛАСНИКІВ НА УРОКАХ УКРАЇНСЬКОЇ МОВИ ГІРСЬКОЇ ШКОЛИ УКРАЇНСЬКИХ КАРПАТ}

Анотація. У статті розглядається проблема роботи зі стійкими мовними зворотами, з якими діти знайомляться ще на початковому етапі навчання мови. Фразеологізми репрезентовані в усіх сферах життя людини, їх діти чують з уст батьків та знайомих щодня, а тому стають зрозумілими і входять у щоденний ужиток. у гірських регіонах, де виховання відбувається у тісному зв'язку з природою, з дещо обмеженим колом спілкування та специфікою умов проживання, дитина досконало змалечку засвоює мовні багатства власної говірки чи говору, у тому числі й стійкі вислови. Однак коли діти знайомляться з підручниками, то часто у молодших школярів виникають проблеми з розумінням і усвідомленням змісту деяких фразеологізмів, які на даній території не вживаються або використовуються рідко. Програма початкової школи передбачає тільки поверхове ознайомлення зі стійкими виразами, що спонукає деяких учителів до несистематичної роботи над фразеологізмами. У статті наводяться результати анкетування вчителів Карпатського регіону з різним рівнем досвіду роботи. Аналіз опитування дозволив зробити висновок, що робота з фразеологізмами у початковій школі носить фрагментарний характер. Зроблена спроба проаналізувати дидактичне наповнення діючих навчальних книг з української мови для третього класу дозволила дійти висновків про те, що більшість вправ мають репродуктивний характер, хоча наявні й такі, що містять творчі елементи завдань. На думку автора статті, схвалення заслуговує підручник для третього класу нової української школи (укладач - Г.Сапун). У статті наведено приклади прийомів роботи з гуцульськими фразеологізмами на уроках української мови у третьому класі. Поданий дидактичний матеріал може бути використаний як у процесі вивчення фразеологізмів у системі підготовки студентів вищих навчальних закладів, так і для розвитку пізнавальної активності учнів початкової школи на уроках української мови, літературного читання.

Ключові слова: українська мова, фразеологізм, прислів'я, гуцульський говір, початкова школа, підручник.

\section{PHRASEOLOGIES AS A MEANS OF SPEECH DEVELOPMENT OF THIRD GRADE STUDENTS IN UKRAINIAN LANGUAGE LESSONS OF THE MOUNTAIN SCHOOL OF THE UKRAINIAN CARPATHIANS}

\footnotetext{
Abstract. The article considers the problem of working with stable language expressions, with which children get acquainted at the initial stage of language learning. Phraseologisms are represented in all spheres of human life, their children hear from parents and acquaintances every day, and therefore they become clear and come into daily use. In mountainous regions, where upbringing takes place in close connection with nature, with a somewhat limited range of communication and the specifics of living conditions, the child perfectly learns from an early age the linguistic richness of his own speech or speech, including stable expressions. However, when children get acquainted with textbooks, younger students often have problems understanding and understanding the content of some phrases that are not used or rarely used in this area. The primary school curriculum provides only a cursory introduction to stable expressions, which encourages some teachers to work unsystematically on phraseology. The article presents the results of a survey of teachers in the Carpathian region with different levels of work experience. The analysis of the survey allowed us to conclude that the work with phraseology in primary school is fragmentary. An attempt to analyze the didactic content of existing textbooks on the Ukrainian language for the third grade led to the conclusion that most exercises are reproductive in nature, although there are those that contain creative elements of tasks. According to the author of the article, the textbook for the third grade of the new Ukrainian school deserves approval (compiled by G. Sapun). The article gives examples of methods of working with Hutsul phraseology in Ukrainian language lessons in the third grade. The given didactic material can be used both in the process of studying phraseology in the system of preparation of students of higher educational institutions, and for development of cognitive activity of pupils of elementary school at lessons of the Ukrainian language, literary reading
}

Keywords: Ukrainian language, phraseology, proverbs, Hutsul dialect, primary school, textbook. 


\section{ВСТУП}

Постановка проблеми. Здатність володіти мовленням $€$ важливою умовою становлення особистості. Процес розвитку мовлення, започаткований ще на етапі первинного засвоєння мови, відбувається упродовж усього освітнього періоду дитини. Зі стійкими мовними зворотами дитина знайомиться ще перебуваючи в сім'ї, поглиблює свої знання у початковій школі, а далі - на наступних етапах освіти. Саме в родинному колі дитина вбирає в себе усю барвистість рідної мови, засвоює тонкі нюанси значення традиційно стійких виразів та закони доречності їх уживання. Потрапляючи до школи, учень опановує нові слова, слухаючи вчителя, читаючи навчальні книги, використовуючи наочні посібники, різні навчальні матеріали, розширює власний запас стійких висловів-фразеологізмів.

Розвиток мовлення дитини у гірських районах має свою специфіку. Він зумовлений спілкуванням із значно звуженим колом мовців, що пов'язано з територіальними особливостями: часто значні відстані між мешканцями не дозволяють щоденно бути у контактах. Тому діти засвоюють той рівень мовлення, яким користуються на щодень їх найближчі рідні, а отже, і запам'ятовують усі вирази, в тому числі й фразеологізми, та їх уживання.

Зрозуміло, що, розпочинаючи навчання в гірській школі Карпатського регіону, молодші школярі уже $€$ носіями гуцульського говору.

Як відомо, гуцульський говір, - один із найбільш самобутніх, найцікавіших і найархаїчніших говорів південнозахідного наріччя української мови. Йому властива ціла система фонетичних, граматичних, лексичних ознак, цей говір має й значний прошарок фразеологізмів. Молодші школярі добре розуміють значення частини цих стійких мовних зворотів, уміють їх правильно уживати.

У навчальних книгах їм трапляються слова й фразеологізми, значення яких відоме частково, або й зовсім не відоме. Тоді власне учитель повинен докласти чималих зусиль, щоб правильно спрямувати учнів на засвоєння нового виразу, що в кінцевому результаті стане шляхом до розвитку мовної компетентності школяра.

Особливі погодні умови проживання молодших школярів у гірських умовах, великі відстані, тісний зв'язок 3 весняними та осінніми польовими роботами - все це диктує потребу організації навчання молодшого школяра в умовах гірської школи таким чином, щоб націлити дитину на самостійне навчання та максимально спростити маленькому школяреві здобуття знань, передбачених навчальною програмою.

У Державному стандарті початкової освіти серед ключових компетентностей молодшого школяра зазначено: «вільне володіння державною мовою, що передбачає уміння усно і письмово висловлювати свої думки, почуття, чітко та аргументовано пояснювати факти, а також любов до читання, відчуття краси слова, усвідомлення ролі мови для ефективного спілкування та культурного самовираження, готовність вживати українську мову як рідну в різних життєвих ситуаціях». Таким чином, мовна компетентність молодшого школяра за чотири роки навчання формується усіма видами мовленнєвої діяльності і має на меті збагачення словникового запасу та досконалого оволодіння граматичними особливостями усного і писемного мовлення для вільної комунікації.

У цьому сенсі велику роль відіграє національне виховання молодших школярів на основі народних традицій. у зв'язку з цим важливого значення набуває розв'язання проблеми формування культури спілкування учнів з опорою на фразеологічне багатство української мови - стійкі сполучення слів, використовувані мовцями вербально та невербально. Фразеологізми становлять доволі об'ємний пласт мовних одиниць, що сприймаються носіями мови автоматично, за традицією, і є відображенням душі народу, його національного мислення, втіленням своєрідності сприйняття і розуміння світу, поведінкових ситуацій та шляхів виходу з них; вони надають висловлюванням емоційності, виступають засобом вираження влучності, дотепності, забезпечують передачу глибини змісту сказаного. А для молодших школярів фразеологізми є засобом формування мовленнєвої компетентності.

Аналіз наукових досліджень і публікацій. Сучасна методика збагачення мовлення учнів фразеологізмами використовує базу українського і російського теоретичного мовознавства (праці О.О.Потебні, Ф.І.Буслаєва, К.Д.Ушинського, О.О.Шахматова, С.Х.Чавдарова, В.І.Масальського, І.С.Олійника, О.М.Біляєва, В.Д.Ужченка, О.О.Бистрової та ін.).

У методиці української мови аналізувалось усне і писемне мовлення учнів, робились спроби розкрити зміст функціонально-стилістичних аспектів вивчення мовних явищ (праці Л.Г.Скрипник, Н.Д.Бабич, В.Я.Мельничайка, А.О.Свашенко, Л.М.Стоян, А.П.Коваль, М.Я.Плющ, М.І.Пентилюк, В.Г.Барабаш, М.П.Коломійця, М.С. Вашуленка). Разом з тим у сучасній методиці обмаль праць фундаментального характеру, присвячених саме методиці роботи 3 фразеологізмами на уроках української мови у початковій школі.

МЕТА І ЗАВДАННЯ ДОСЛІДЖЕННЯ - аналіз дидактичного змісту діючих підручників для 3 класу 3 української мови на предмет наповнення фразеологічним матеріалом та розробка шляхів активізації розвитку мовлення школярів гірських регіонів Карпат засобами української фразеології.

\section{МЕТОДИ ДОСЛІДЖЕННЯ}

У процесі підготовки матеріалу використано методи: теоретичні - вивчення, аналіз теоретичних даних, представлених у лінгвістичній, педагогічній та методичній літературі; аналіз сучасних наукових досліджень і законодавчої бази національної освіти, навчальних книг для дітей молодшого шкільного віку, фольклорних джерел тощо; емпіричні - педагогічне спостереження, аналіз навчально-методичної документації, навчальних програм, вивчення педагогічного досвіду вчителів початкової школи.

\section{РЕЗУЛЬТАТИ ДОСЛІДЖЕННЯ}

Фразеологічні вміння молодших школярів, як і учнів середньої ланки освіти, інтегровані в більшість навчальних предметів, передбачених базовим навчальним планом початкової освіти, тому вивчення фразеологізмів у сучасній 
початковій школі має як внутрішньо-предметний, так і міжпредметний характер. Аналіз методичної літератури та законодавчої документальної бази свідчить про доцільність і можливість організації роботи з фразеологізмами з метою формування комунікативної компетентності молодших школярів.

У програмах середньої загальноосвітньої школи 1-4 класів особлива увага звертається на засвоєння лексичного багатства української мови і вироблення практичних навичок користування ним у повсякденному житті, а також на засвоєння основ граматики української мови та основних орфографічних норм. Аналіз навчальних програм з української мови засвідчив, що фразеологізми як предмет вивчення не знайшли систематичного відображення у цих документах.

Так, «Типова освітня програма, розроблена під керівництвом Савченко О. Я. 3- 4 клас» (2019, с. 12-13) вивченню фразеологізмів рекомендує аж 4 клас. У першому-третьому класах учні тільки виконують вправи з уміщеними в них прислів'ями - в основному ці вправи носять репродуктивний характер. Зрозуміло, що такий підхід цілком методично виправданий, однак, окрім прислів'їв, поза увагою дітей залишається значний шар фразеологізмів інших видів. Рівень ознайомленості учнів 1-3 класів з фразеологізмами залежить насамперед від уміщеного у підручники фразеологічного матеріалу, а тому наповнення їх потребує надзвичайно ретельного і виваженого підходу в плані добору найбільш уживаних стійких виразів, а тому таких, що легко сприймаються дітьми.

Несистематичність фразеологічної роботи на уроках української мови в початкових класах, відсутність науково обґрунтованої системи організації занять є однією з вагомих причин обмеженого вживання фразеологізмів молодшими школярами.

Ми провели серед учителів Карпатського регіону опитування, що стосувалося питань оптимізації роботи над розвитком мовлення з учнями початкової школи. В анкетуванні взяли 25 учителів з різним стажем педагогічної роботи.

Так, ми запропонували відповісти на питання «Чи розрізняють у текстах учні незрозумілі для них вирази, в тому числі й фразеологізми?» і вивели такі варіанти відповідей:

- так;

- ні;

- інколи;

- учні не звертають увагу і не помічають такі вислови.

Опитування засвідчило, що тільки 3 вчителі зазначили, що учні в текстах розрізняють незрозумілі для них вирази, в тому числі і фразеологізми. 10 вчителів написали, що учні бачать незрозумілі вирази інколи, тобто, учні читаючи різноманітні тексти, можуть розрізняти ті фразеологізми, на які вони натрапляли у мовленні раніше, а тому вони $€$ зрозумілими; а важчі - ні. 9 вчителів зазначили, що учні ніколи не розрізняють такі вирази, а це свідчить про те, що попросту вчитель недостатньо акцентує увагу на нових виразах. 3 респонденти вибрали 4 варіант відповіді, що теж говорить про недостатню методичну роботу педагогів.

Наступним було запитання «Які прийоми роботи над фразеологізмами, на Вашу думку, є найбільш оптимальними для роботи з учнями початкової школи?

- звертання до пояснення, запропонованого у підручнику;

- пояснення виразу учителем;

- звертання до довідкової літератури, в тому числі й словника;

- поєднання декількох варіантів або вкажіть свій варіант».

Переважна більшість - 14 учителів - зазначили, що звертаються до пояснення, запропонованого у підручнику. Прикро, але роботу зі словником вважає оптимальною невелика кількість учителів - лише 3 . Тільки 4 вважають найбільш дієвим пояснення фразеологізму вчителем. Серед опитуваних були такі, що обирали водночас і використання словника, і додаткову літературу, і пояснення з підручника, і власне пояснення, або ж пропонували інший варіант: в ігровій формі спрямовувати учнів самостійно виходити на значення фразеологізму, без додаткових пояснень учителя чи звертань до підручника.

Ми запропонували учителям дати відповідь на запитання «Чи можуть учні самостійно тлумачити значення виразів?

- так, завжди;

- так, коли дитина багато читає;

- так, коли з дитиною систематично працюють батьки;

- майже ніколи;

- ніколи»

Всього 7 учителів зазначили, що їхні учні можуть самостійно тлумачити значення виразів та використовувати їх в усному та писемному спілкуванні, бо знайомляться з ними у книжках; 5 учителів зазначили, що успішне розуміння і вживання фразеологізмів пов'язане з тим, що батьки ретельно дома працюють з дітьми; 9 учителів відповіли, що учні майже ніколи не можуть самостійно тлумачити значення виразів; 4 вчителі - учні взагалі ніколи не тлумачать самостійно фразеологізми.

Наступними були запитання, які дозволили нам впритул підійти до аналізу методичного наповнення навчальних книг з української мови для початкової школи: «Які фразеологізми, на Ваш погляд, є найважчими для опанування учнями? Наведіть приклади стійких виразів - з підручників для початкової школи або зі сфери усного мовлення» і «Які фразеологізми, з Вашого погляду, є найлегшими в опануванні учнями? Наведіть приклади фразеологізмів - $з$ підручників для початкової школи або зі сфери усного мовлення».

Учителі зазначили, що найважчими для опанування учнями є фразеологізми: пекти раків, ахіллесова п'ята, зуб на зуб не попадає, сидіти в печінках, волосся стало дибом, сісти на голову, палець об палець не вдарить, наламати 
дров, на головах ходять, пасти задніх, дивитися крізь пальці; міняти шило на мило; проміняв бики на воли; пасти очима; очі мої б тебе не бачили; відняти мову; з легким серцем; у живі очі; на заячий скік; як горох при дорозі; з'їсти собаку, аж іскри летять, цур тобі й пек, важлива птиця, нести свій хрест, розбити глека;

найлегшими - бити байдики, не робити з мухи слона, двох слів докупи не зв'язати; взяти ноги на плечі; набрати води в рот; викинути з голови, вертітися під ногами; замилювати очі; кидати слова на вітер; знати на зубок, тяжкий хліб; ані пари з вуст; світ за очі; битий шлях; хоч сядь та й плач; розуму не спали; наче у воду опущені; куди очі дивляться, відняти мову; з легким серцем; у живі очі; гнути спину; на краю світу, повісити носа, як кіт наплакав, не видавиш слова, у поті чола, язик без кісток, як мокре горить, не вірю своїм очам, бути в курсі, бути на сьомому небі.

Як бачимо, серед важких для сприйняття молодших школярів стійких висловів опинилися фразеологізми давнього походження (ахіллесова п'ята, нести свій хрест), у яких є архаїми та історизми (цур тобі й пек), а також ті, виникнення яких пов'язане з певною професією (проміняв бики на воли, пасти задніх, пасти очима). Разом з тим, серед важко зрозумілих учителі не назвали ні одне прислів'я чи приказку, що свідчить про те, що укладачі підручників для початкової школи взяли правильне спрямування на те, щоб умістити у ці навчальні книги максимально зрозумілі для дітей вислови, якими і є народні прислів'я - вислови з глибоким дидактичним змістом та переважно чіткою ритмомелодикою.

Опитування учителів дозволило підтвердити наші припущення, що робота над фразеологізмами з учнями початкової школи носить в основному несистематичний, фрагментарний характер, в результаті чого поза увагою дітей залишається доволі значний об'єм мовних конструкцій, які забезпечують не тільки більш точне вираження думки у процесі комунікації, а й сприяють розвитку мовленнєвої компетентності молодших школярів.

Ми проаналізували дидактичне наповнення найчастіше використовуваного у школах Прикарпаття та Карпатського регіону підручника з української мови для третьокласників.: Українська мова: підручник для 3 класу загальноосвітніх навчальних закладів.(Захарійчук М.Д., Мовчун А.І., 2013). Розглядаючи розміщені в даному підручнику вправи за ступенем самостійності, можна помітити, що більшість носить репродуктивний характер. I це цілком виправдано та методично правильно. Адже третьокласники тільки починають знайомитись зі сталими виразами, спостерігають за їх значенням і вживанням, вчаться розпізнавати їх у тексті. Так, на самому початку автор пропонує дітям записати і пояснити значення прислів'я «Слово, наче птах, народжується з крилами». Серед вправ з фразеологізмами у підручнику вміщені і так звані конструктивні вправи, що дозволяють учням зупинитись на змісті відомих їм прислів'їв та вибрати з пропонованих виразів закінчення. Так, на с. 27 учні добирають 3 другої частини серед кількох пропонованих правильне закінчення прислів'я: «Хто більше читає, той // більше знає», «Книжка мовчки все // розкаже» і т.д. Підручник пропонує учням з'єднувати частини прислів'їв ще в декількох вправах, знаходячи антоніми, добираючи синоніми, а також складати речення з поданими фразеологізмами. Відрадно, що для роботи беруться не тільки прислів'я, а й фразеологічні зрощення та єдності, але всі -такі, що часто вживаються у повсякденному житті, а тому будуть відомими для дітей початкової школи.

Працюючи за цим підручником, учитель карпатської гуцульської школи значно увиразнить та активізує пізнавальну активність третьокласників, якщо запропонує учням до пропонованих дібрати такі, які використовують на щодень їх батьки чи інші родичі. Так, на с. 47, учні розглядають значення фразеологізму «тримати язик за зубами». Учитель може попросити дітей згадати прислів'я подібного змісту, яке у вжитку в гуцульському говорі: «Мовчи, язичку, будеш їсти кашку».

Окремої уваги заслуговує підручник Г.Сапун, розрахований на нову програму для третьокласників (Сапун Г., 2019). У ньому набагато більше урізноманітнено вправи, у яких містяться фразеологізми. Суттєво зросла питома вага завдань з творчими елементами, що розраховані на варіативність та індивідуальність виконання, збільшилась кількість вправ на конструювання та моделювання фразеологізмів, заміну одних елементів іншими. Розширений тематичний діапазон дидактичного спрямування фразеологізмів: про роль книги, праці в житті людини, чесність, сміливість, працелюбність, прагнення до знань тощо. Укладач звертає увагу учнів на те, що інформацію про фразеологізм вони можуть почерпнути у фразеологічному словнику - це спрямує третьокласника на шлях самостійного пошуку нових знань та поглиблення вивченого.

В аналізованих підручниках учні знайдуть інформацію, що бувають фразеологізми - антоніми та фразеологізми синоніми. Учителям гірської школи Карпатського регіону варто використати фразеологічне багатство гуцульської говірки і залучити цей матеріал у процесі опанування фразеологізмів на уроках української мови. Так, учитель подасть доволі частотні українські прислів'я і приказки та запропонує дібрати такі, що є у використанні мешканців Карпатського краю:

Народні фразеологізми гуцульські фразеологізми

Хто в ліс, хто по дрова // одне в луг, друге в плуг.

3 ким поведешся -такого й наберешся // з ким пристаєш - таким ся стаєш.

З вогню та в полум'я // з дощу та під ринву.

Хто рано встає, тому бог дає // ранок-панок.

Як постелиш, так виспишся // як дбаєш, так маєш.

Ні риба, ні м'ясо // ні лій, ні масло.

Ні в кут, ні в двері // Ні до танцю, ні до ружанцю.

Своя сорочка ближче до тіла // чужий кожух зле гріє.

\section{ВИСНОВКИ ТА ПЕРСПЕКТИВИ ПОДАЛЬШИХ ДОСЛІДЖЕНЬ}

Фразеологізми як неподільні одиниці становлять собою доволі значний мовний пласт, що функціонує на всіх рівнях комунікації. Вони активно входять у словниковий запас уже на рівні первинного опанування мови, а тому вчителеві початкового етапу освіти важливо не випустити з поля зору роботу над фразеологізмами, хоча й 
програма початкової школи передбачає тільки поверхове ознайомлення з ними, і то не з першого року навчання. Анкетування вчителів шкіл регіону Карпат засвідчило, що фразеологізми досить часто є незрозумілими для учнів початкової школи - носіїв гуцульського говору, а тому робота над ними вимагає особливих зусиль, послідовності і систематичності. Обсяг фразеологічного матеріалу, його характер, прийоми роботи над фразеологізмами повною мірою залежать від вибору вчителя, який зважає на загальний рівень розвитку дітей, їх начитаність, мовлення, життєвий досвід тощо. Доволі дієвим є прийом зіставляння загальноукраїнських фразеологізмів з такими, що є часто вживаними в Карпатах та Прикарпатті.

Обсяг статті не дозволив розкрити проблему роботи з фразеологізмами у гірській школі Карпатського регіону на інтегрованих уроках української мови та літературного читання у новій початковій школі, що становить перспективу подальших досліджень.

Сучасні реалії оновлення освіти диктують потребу реалізації нових підходів і в доборі матеріалів щодо опрацювання фразеологізмів з молодшими школярами. Саме це стане запорукою розвитку нової української школи, яка покликана формувати компетентнісно активну особистість, здатну до повноцінної комунікації.

\section{СПИСОК ВИКОРИСТАНИХ ДЖЕРЕЛ}

Державний стандарт початкової освіти. Затверджено Постановою Кабінету Міністрів України від 27 лютого 2018 р. № 87. С. 2. https://www.kmu.gov.ua/npas/pro-zatverdzhennya-derzhavnogo-standartu-pochatkovoyi-osviti Останнє звернення 28.04.20120

Типова освітня програма, розроблена під керівництвом Савченко О. Я. 3- 4 клас. Наказ МОНу 08.10.2019 року № 1273 https://mon. gov.ua/storage/app/media/zagalna\%20serednya/programy-1-4-klas/2019/11/3-4-dodatki.pdf. Останнє звернення 28.04.20120

Українська мова: підручник для 3 класу загальноосвітніх навчальних закладів./ М.Д. Захарійчук, А.І.Мовчун К.:Грамота, 2013,176 с.

Г.Сапун. Українська мова та читання: посібн. для 3 кл. закл. загал. середн. освіти. У 4 ч. Ч. 1. Тернопіль : Підручники і посібники, 2019. $64 \mathrm{c}$

\section{REFERENCES}

Dergjavnyi standart pochatkovoji shkoly. Zatverdgjeno Postanovoju kabinetu Ministriv Ukrainy vid 27 lutogo 2018 r. №87. P.2. [State standard of primary education. Approved by the Resolution of the Cabinet of Ministers of Ukraine of February 27, 2018. №87] URL: https://www.kmu. gov.ua/npas/pro-zatverdzhennya-derzhavnogo-standartu-pochatkovoyi-osviti [in Ukrainian].

Typova osvitnja programa, rozroblena pid kerivnyctvom Savchenko O.Ja. 3-4 klas. Nakaz MONU 08.10.2019 roku № 1273 [A typical educational program developed under the guidance of Savchenko O. Ya. 3- 4 class. Order of the Ministry of Education and Science of October 8, 2019 № 1273]

URL: https://mon.gov.ua/storage/app/media/zagalna\%20serednya/programy-1-4-klas/2019/11/3-4-dodatki.pdf. [in Ukrainian].

Zakharijchuk M.D., Movchun A.I. Ukrainska mova: pidruchnyk dla 3 klasu zagalnoosvitnih navchalnyh zakladiv.K;Gramota,[ Ukrainian language: a textbook for the 3rd grade of secondary schools.]2013, 176 p. [in Ukrainian].

G. Sapun. Ukrainska mova ta chytanna: posibn. dla 3 kl. Zakl.zagal.seredn.osvity. U 4 ch. Ch.1. Ukrainian language and reading: manual. for 3 classes. lock total. average education. In 4 p. Part 1. Ternopil: Pidruchnyky I posibnyky, 2019. 64 p.[in Ukrainian]. 